\begin{tabular}{|c|l|}
\hline Title & Partitioning and recovery of proteinase from tuna spleen by aqueous two-phase systems \\
\hline Author(s) & Klomklao, Sappasith; Benjakul, Soottawat; V isessanguan, Wonnop; Simpson, Benjamin K.; Kishimura, Hideki \\
\hline Citation & $\begin{array}{l}\text { Process Biochemistry, 40/9), 3061-3067 } \\
\text { https://doi.org/L0.1016/.procbio.2005.03.009 }\end{array}$ \\
\hline Issue Date & $2005-09$ \\
\hline Doc URL & http://hdl.handle.net/2115/8467 \\
\hline Type & article (author version) \\
\hline File Information & ProcessBiochemmanuscript.pdf \\
\hline
\end{tabular}

Instructions for use 


\section{Partitioning and recovery of proteinase from tuna spleen by aqueous two-phase systems}

To be submitted to

Process Biochemistry

Sappasith Klomklao ${ }^{1}$, Soottawat Benjakul ${ }^{1 *}$, Wonnop Visessanguan ${ }^{2}$, Benjamin K. Simpson ${ }^{3}$ and Hideki Kishimura ${ }^{4}$
${ }^{1}$ Department of Food Technology, Faculty of Agro-Industry, Prince of Songkla University, Hat Yai, Songkhla, 90112, Thailand.
${ }^{2}$ National Center for Genetic Engineering and Biotechnology, National Science and Technology Development Agency, 113 Paholayothin Rd., Klong 1, Klong Luang, Pathumthani, 12120, Thailand.
${ }^{3}$ Department of Food Science and Agricultural Chemistry, McGill University, Macdonald campus, 21111 Lakeshore Road, Ste. Anne de Bellevue, Quebec, Canada H9X 3V9.
${ }^{4}$ Graduate School of Fisheries Sciences, Hokkaido University, Hakodate, Hokkaido, 041-8611, Japan.

\footnotetext{
*To whom correspondence should be addressed. Tel: 66-7428-6334.
}

Fax: 66-7421-2889, e-mail: soottwat.b@psu.ac.th 

(2) 0

\section{Abstract}

Partitioning of spleen proteinase from yellowfin tuna (Thunnus albacores) in an aqueous two-phase system (ATPS) was investigated. Phase compositions including PEG molecular mass and concentration as well as types and concentration of salts affected the protein partitioning. ATPS comprising PEG1000 (15\% w/w) and magnesium sulfate $(20 \% \mathrm{w} / \mathrm{w})$ provided the best condition for the maximum partitioning of the proteinase into the top phase and gave a highest specific activity (47.0 units/ug protein) and purification fold (6.61). The yield of 69.0\% was obtained.

Under the same ATPS condition used, the partitioning of proteinase of splenic extract from three tuna species involving skipjack tuna, yellowfin tuna and tongol tuna were compared. The purity of splenic extract from all tuna species increased after ATPS process. Among all species tested, yellowfin tuna showed the highest purification fold, followed by tongol tuna and skipjack tuna, respectively. SDS-substrate gel electrophoresis revealed that the band intensity of major proteinase in ATPS fraction from all tuna species slightly increased with the concomitant decrease in band intensity of other contaminating proteins, indicating the greater specific activity of splenic extract. Therefore, ATPS was an effective method for partitioning and recovery of proteinases from tuna spleen.

Keywords: Aqueous two-phase system; Proteinase; Purification; Spleen; Tuna

(3)

4

(6)




\section{Introduction}

Tuna processing industry, especially canning, has become increasingly important as an income generator for Thailand. In terms of volume, Thailand is the world's largest exporter of canned tuna, for over 20 million cans annually during the past 5 years [1,2]. Large volumes of raw tuna go through the canning process, by which about two-third of the whole fish are utilized. As a consequence, processing wastes from the tuna canning industry are generated and estimated at 450,000 metric tons annually [1]. More than 200,000 metric tons of tuna viscera and offal can be collected and used mostly for animal feed.

Fish viscera is a potential source for recovering enzymes such as proteinases that may have some unique properties for industrial applications; e.g. in the detergent, food, pharmaceutical, leather and silk industries [3-7]. The use of alkaline proteinases has increased remarkably since they are both stable and active under harsh conditions such as at temperatures of 50 to $60^{\circ} \mathrm{C}$, high pHs and in the presence of surfactants or oxidizing agents $[7,8]$.

Trypsins have been characterized thoroughly based on their physicochemical and enzymatic properties from the intestine of crayfish [9,10], dogfish [11], mackerel [12] and capelin [13]. Bezerra et al. [14] partially purified trypsin from pyloric caeca of tambaqui (Colossoma macropomum) and found that the enzyme had an optimal pH of 9.5. Byun et al. [15] purified and characterized serine proteinases from pyloric caeca of tuna (Thunnus thynnus). Recently, Klomklao et al. [2] reported that major proteinases in spleen of three tuna species including skipjack tuna, yellowfin tuna and tongol tuna were trypsin-like serine proteinases. Among the spleen from three species, that from yellowfin tuna showed the highest activity. 
Partitioning in an aqueous two-phase system (ATPS) is a selective method

2 used for biomolecule purification [16]. Aqueous two-phase system is generally

3 formed by mixing two or more incompatible polymers in aqueous condition. Phase

4 separation occurs over certain concentrations of phase components. Alternatively,

5 polymer and salt can also be used to generate an aqueous two-phase [16]. Among the

6 polymer/salt systems, polyethylene glycol (PEG)/potassium phosphate and

7 PEG/magnesium sulphate are most frequently used [17-19]. Generally, the

8 biomolecule partition coefficient, $\mathrm{K}$, defined as the ratio of the biomolecule

9 concentration in the top phase to that in the bottom phase, was used to quantify the

10 biomolecule partition behaviour. If the partition coefficients (or ratios) of two

11 substances differ by a factor of 10 or more, their separation can be satisfactorily

12 carried out [20]. When a single component must be extracted from a mixture, phase

13 system compositions are often manipulated in such a manner that the component

14 partitions into one of the phases, while the other components of the mixture partition

15 into the other phase [20]. Additionally, the surface charge of biological materials is

16 one of the most significant factors affecting the separation by use of partitioning [21].

17 Molecular weight, shape, hydrophobicity and specific binding sites of biological

18 materials also affect the partition profiles. Electrical interaction and repulsion between

19 charged aqueous phase systems and the proteins affect the partitioning of system [21].

ATPS have found application in the industrial scale purification of proteins

21 from biomass [22]. The use of ATPS in downstream processing has been focused on

22 the extraction, separation and concentration of various biomolecules including

23 xylanases [23], amylase [24], anyloglucosidase [25], amino acid [26], etc. However,

24 sometimes it is used as a potential primary purification technique to reduce the bulk of

25 the processing stream, if not the only step to be followed by more selective final 
1 purification steps such as chromatography, electrophoresis, etc [27]. Industries desire

2 procedures which are less time consuming and give high enzyme yields with

3 considerable purity. In this regard, partitioning in ATPS provides a powerful method

4 for separating and purifying mixtures of proteins [23-25]. ATPS also offers many

5 advantages including low process time, low energy consumption and biocompatible

6 environment to the biomolecule due to the presence of large amounts of water in the

7 extraction systems [22]. Furthermore, ATPS can remove contaminants such as nucleic

8 acids and undesirable proteins. Hence, ATPS has been recognized as an efficient and

9 economical downstream processing method due to the ease and lower cost [22, 28].

10 Our objective was to investigate the feasibility of utilizing ATPS for partitioning and 11 recovery of proteinase from tuna spleen. 


\section{2. Materials and methods}

\subsection{Chemicals}

Polyethylene glycol (PEG) 1000 and 4000 were obtained from Wako Pure Chemical Industries, Ltd. (Tokyo, Japan). Sodium caseinate, $\beta$-mercaptoethanol ( $\beta \mathrm{ME})$, L-tyrosine, high-molecular-weight markers, low-molecular-weight markers and bovine serum albumin were purchased from Sigma Chemical Co. (St. Louis, MO, USA.). Trichloroacetic acid, tris (hydroxymethyl) aminomethane and FolinCiocalteu’s phenol reagent were obtained from Merck (Darmstadt, Germany). Sodium dodecyl sulfate (SDS), Coomassie Blue R-250 and $N, N, N^{\prime}, N^{\prime}$-tetramethyl ethylene diamine (TEMED) were purchased from Bio-Rad Laboratories (Hercules, CA, USA). The salts and other chemicals with the analytical grade were procured from Merck (Darmstadt, Germany).

\subsection{Fish Sample preparation}

Internal organs from three species of tuna including skipjack tuna (Katsuwonus pelamis), yellowfin tuna (Thunnus albacares) and tongol tuna (Thunnus tonggol) were obtained from Chotiwat Industrial Co. (Thailand) Ltd., Songkhla. Those samples (5 kg) were packed in the polyethylene bag, kept in ice and transported to the Department of Food Technology, Prince of Songkla University, Hat Yai, Thailand within 30 min. Pooled internal organs were then excised and separated into individual organs. Only spleen was collected, immediately frozen and stored at $-20^{\circ} \mathrm{C}$ until used. 


\subsection{Preparation of spleen extract}

Frozen spleens were thawed using a running water $\left(26-28^{\circ} \mathrm{C}\right)$ until the core temperature reached -2 to $0^{\circ} \mathrm{C}$. The samples were cut into pieces with a thickness of 1-1.5 cm. Samples were ground into powder in the liquid nitrogen using a National Model MX-T2GN blender (Taipei, Taiwan) according to the method of Simpson and Haard [29] as modified by Garcia-Carreno et al. [30].

Spleen powder was suspended in the distilled water at a ratio of 1:9 (w/v) and stirred continuously at $4^{\circ} \mathrm{C}$ for $15 \mathrm{~min}$. The suspension was centrifuged for $15 \mathrm{~min}$ at $4^{\circ} \mathrm{C}$ at 5,000×g using a Sorvall Model RC-B Plus centrifuge (Newtown, CT, USA) to remove the tissue debris. The supernatant was collected and referred to as "tuna spleen extract”.

\subsection{Enzyme assay}

Proteinase activity of spleen extract from each tuna was determined using casein as a substrate according to the method of An et al. [31] with a slight modification. To initiate the reaction, $200 \mu$ diluted spleen extract (500 folds) was added into assay mixtures containing $2 \mathrm{mg}$ of casein, $200 \mu \mathrm{l}$ of distilled water and 625 $\mu \mathrm{l}$ of assay buffer (0.1 M glycine- $\mathrm{NaOH}, \mathrm{pH} 9.0)$. The mixture was incubated at $55^{\circ} \mathrm{C}$ for precisely 15 min. Enzymatic reaction was terminated by adding $200 \mu$ l of $50 \%$ (w/v) trichloroacetic acid (TCA). Unhydrolyzed protein substrate was allowed to precipitate for $15 \mathrm{~min}$ at $4^{\circ} \mathrm{C}$, followed by centrifuging at $7,000 \times \mathrm{g}$ for $10 \mathrm{~min}$. The oligopeptide content in the supernatant was determined by the Lowry assay [32] using tyrosine as a standard. One unit of activity was defined as that releasing 1 nmole of 
1 tyrosine per min (nmol/Tyr/min). A blank was run in the same manner, except the enzyme was added after addition of $50 \%$ TCA (w/v).

2.5 Preparation of aqueous two phase systems

ATPS were prepared in a 10 -ml centrifuge tubes by adding the appropriate

6 amount of PEG, salts and tuna spleen extract. To study the effect of salts on

7 partitioning the proteinase from tuna spleen extract using ATPS, different salts

8 including $\mathrm{NaH}_{2} \mathrm{PO}_{4}, \mathrm{~K}_{2} \mathrm{HPO}_{4}, \mathrm{MgSO}_{4}, \mathrm{Na}_{3} \mathrm{C}_{6} \mathrm{H}_{5} \mathrm{O}_{7},\left(\mathrm{NH}_{4}\right)_{2} \mathrm{SO}_{4}$ and $\mathrm{Na}_{2} \mathrm{SO}_{4}$ at

9 different concentrations (15, 20 and 25\% w/w) were mixed with 20\% PEG1000 in

10 aqueous system. Distilled water was used to adjust the system to obtain the final

11 weight of $5 \mathrm{~g}$. The mixtures were mixed continuously for 3 min using a Vortex mixer

12 (Vortex-genie2, G-560E, USA). Phase separation was achieved by centrifugation for

$135 \mathrm{~min}$ at $2000 \times \mathrm{g}$. Top phase was carefully separated using a pasteur pipette and the

14 interface of each tube was discarded. Volumes of the separated phases were measured.

15 Aliquots from each phase were taken for enzyme assay and protein determination.

Purification factor (PF), defined as the ratio of specific proteinase activity

17 (SA) of each phase to the initial specific proteinase activity of crude extract was

18 calculated. Partition coefficient $\left(\mathrm{K}_{\mathrm{E}}\right.$ or $\left.\mathrm{K}_{\mathrm{P}}\right)$, the ratio of enzyme activity or protein

19 concentration in the top phase to that in the bottom phase was also calculated. The

20 volume ratio $\left(V_{R}\right)$ defined as the ratio of volume in the top phase to that in the bottom

21 phase was recorded.

To study the effect of the concentrations $(10,15,20$ and $25 \% \mathrm{w} / \mathrm{w})$ of

23 PEG1000 and PEG4000 on partitioning of proteinase in tuna spleen extract, $\mathrm{MgSO}_{4}$ at

24 a level of $20 \%$ was used in the system. Partitioning was performed as previously 
1 described. All experiments were run in duplicate. The ATPS rendering the most

2 effective partitioning was chosen. Phase with high specific activity, was dialyzed

3 against 10 volumes of $50 \mathrm{mM}$ Tris- $\mathrm{HCl}, \mathrm{pH} 7.5$ for $18 \mathrm{~h}$ with 3 changes of buffer in

4 the first $3 \mathrm{~h}$ and 5 changes in the last $15 \mathrm{~h}$.

62.6 Sodium dodecyl sulfate-gel electrophoresis

SDS-PAGE was performed according to the method of Laemmli [33]. Protein solutions were mixed at 1:1(v/v) ratio with the SDS-PAGE sample treatment buffer (0.125M Tris- $\mathrm{HCl} \mathrm{pH}$ 6.8, 4\% SDS, 20\% glycerol, 10\% $\beta$-mercaptoethanol) and boiled for $3 \mathrm{~min}$. The samples (20 $\mu \mathrm{g}$ ) were loaded on the gel made of $4 \%$ stacking and $10 \%$ separating gels and subjected to electrophoresis at a constant current of 15 mA per gel using a Mini-Protean II Cell apparatus. After electrophoresis, the gels were stained with $0.2 \%$ Coomassie brilliant blue R-250 in $45 \%$ methanol and $10 \%$ acetic acid and destained with 30\% methanol and 10\% acetic acid.

\subsection{Activity staining}

Spleen extract and selected phase with high specific proteolytic activity obtained from ATPS were separated on SDS-PAGE, followed by activity staining according to the method of Garcia-Carreno et al. [30]. The samples were mixed with sample buffer (0.125M Tris-HCl, pH 6.8 containing 20\% (v/v) glycerol, 10\% $\beta$ mercaptoethanol) at a ratio of 1:1 (v/v). Two $\mu$ g of proteins were loaded into the gel made of $4 \%$ stacking and $12 \%$ separating gels. The proteins were subjected to electrophoresis at a constant current of $15 \mathrm{~mA}$ per gel by a Mini-Protean II Cell apparatus. After electrophoresis, gels were immersed in $100 \mathrm{ml}$ of $2 \%$ casein (w/v) in 
$150 \mathrm{mM}$ Tris- $\mathrm{HCl}$ buffer, $\mathrm{pH} 7.5$ for $1 \mathrm{~h}$ with constant agitation at $0^{\circ} \mathrm{C}$ to allow the

2 substrate to penetrate into the gels. The gels were then transferred to $2 \%$ casein $(\mathrm{w} / \mathrm{v})$

3 in $0.1 \mathrm{M}$ glycine- $\mathrm{NaOH}, \mathrm{pH} 9.0$ and incubated at $55^{\circ} \mathrm{C}$ for 15 min with constant

4 agitation to develop the activity zone. The gels were fixed and stained with $0.125 \%$

5 Coomassie blue R-250 in 45\% ethanol and 10\% acetic acid and destained in 30\%

6 methanol and $10 \%$ acetic acid. Development of clear zones on blue background

$7 \quad$ indicated proteolytic activity.

8

9 11 bovine serum albumin as a standard.

\subsection{Protein determination}

Protein concentration was measured by the method of Bradford [34] using

\section{Results and discussion}

\subsection{Effect of salts on the proteinase partitioning in ATPS}

The partitioning of spleen proteinase from yellowfin tuna was carried out in several biphasis system of 20\% PEG1000 with different salts, $\mathrm{NaH}_{2} \mathrm{PO}_{4}, \mathrm{~K}_{2} \mathrm{HPO}_{4}$, $\mathrm{MgSO}_{4}, \mathrm{Na}_{3} \mathrm{C}_{6} \mathrm{H}_{5} \mathrm{O}_{7},\left(\mathrm{NH}_{4}\right)_{2} \mathrm{SO}_{4}$ and $\mathrm{Na}_{2} \mathrm{SO}_{4}$ at different concentrations (Table 1). With either PEG1000 or salts alone, no phase separation was observed (data not shown) indicating that the combination of both PEG and salt was necessary for partitioning process. After phase separation, two phases were obtained, PEG-rich top phase and salt-rich lower phase. For all ATPS studied, the proteinase was partitioned predominantly in the PEG-rich top phase, principally those with hydrophobic characteristics [20]. However, the recovery of proteinase from the opposite phase (lower phase) was relatively low. In general, negatively charged proteins prefer the 
1 upper phase in PEG/salt systems, while positively charged proteins normally partition

2 selectively to the bottom phase [35]. Hence, most of spleen proteinases partitioned in

3 top phase might be negatively charged. The maximum SA and PF of proteinase

4 obtained in PEG1000/salt systems depended on the medium composition (Table 1). A

5 phase system containing 20\% PEG1000 and 20\% $\mathrm{MgSO}_{4}$ gave the highest SA (24.5

6 units/ $\mu$ g protein) and PF (3.4 fold). Pan and Li [36] reported that the use of 25\% (w/v)

7 PEG1500 and 20-25\% (w/v) $\mathrm{NaH}_{2} \mathrm{PO}_{4}$ was effective in concentrating and purifying

8 the $\beta$-xylosidase. The system containing $20 \% \mathrm{MgSO}_{4}$ was selected for further study

9 on the effect of PEG concentration on proteinase partitioning.

The distribution of the proteins in ATPS is characterized by partition

11 coefficient $\mathrm{K}$. K values for proteinase and protein partitioning are reported as $\mathrm{K}_{\mathrm{E}}$ and

$12 \mathrm{~K}_{\mathrm{P}}$, respectively. From the result, ATPS with magnesium sulfate at a concentration of

$1320 \%$ showed the lowest $K_{P}(0.32)$ indicating that it caused a shift of contaminant

14 proteins, nucleic acid and other undesirable components to the lower phase. Thus, the

15 extraction conditions employed resulted in the enrichment of specific proteinase

16 activity, which was due to the differential partitioning of the desired proteinase and

17 contaminating enzymes and proteins to the opposite phases. Table 1 also showed that

18 increasing salt concentration resulted in a less activity recovery. Loss in activity might

19 be due to the denaturation of proteinases causes by "salting out" effect [2]. Isable and

20 Otero [35] found that the presence of high concentrations of salt in the reaction

21 medium greatly decreased both the yield and the selectivity towards the trisaccharide

22 from lactose. Pan and $\mathrm{Li}$ [36] also reported that increasing $\mathrm{NaH}_{2} \mathrm{PO}_{4}$ concentration

23 resulted in a less activity recovery as well as a poorer specific activity. Therefore, type

24 of salt and concentration used were critical for yellowfin tuna spleen proteinase

25 recovery or partitioning in ATPS. 
23.2 Effect of PEG molecular weight on the proteinase partitioning in ATPS

Proteinase partitioning in ATPS with varying concentration of PEG and 20\%

$4 \mathrm{MgSO}_{4}$ is shown in Table 2. Partitioning of proteinase in PEG/ $\mathrm{MgSO}_{4}$ system was

5 strongly dependent on the molecular weight of the PEG. With PEG1000, all

6 proteinases partitioned into the top phase $\left(K_{E}>1\right)$. Conversely, most proteinases were

7 partitioned into the lower phase $\left(K_{E}<1\right)$ in ATPS containing PEG4000. Thus, $K_{E}$

8 values depended on the PEG molecular weight. The $K_{P}$ increased when PEG with

9 higher molecular weight was used. However, Reh et al. [20] reported that most

10 proteins were partitioned to the top phase in phase systems with low molecular weight

11 PEG. The influence of the molecular mass of PEG on protein partitioning can be

12 explained on the basis of Flory Huggins theory for polymers in solution [20]. A

13 preferential interaction between the PEG molecule and the protein domain decreased

14 when the molecular mass of PEG increased due to its exclusion from the protein

15 domain [20]. This might lead to the movement of proteinase to the salt lower phase.

16 Additionally, use of the higher molecular weight PEG gave a lower yield of

17 proteinase recovered, compared with the lower molecular weight PEG (Table 2).

18 Fernandez Lahore et al. [37] reported that the use of high molecular weight PEG is

19 unsuitable for purification purpose. Among all ATPS tested, system comprising 15\%

20 PEG 1000 and $20 \% \mathrm{MgSO}_{4}$ partitioned the proteinase to the top PEG-rich phase and

21 undesired protein to the bottom salt phase most effectively. Under the optimal

22 conditions, 69\% of the enzyme was recovered in the top phase, providing

23 approximately 6.6 folds of purification for spleen proteinase of yellowfin tuna.

243.3 Recovery of spleen proteinase from other tuna species 
The 15\%PEG-20\% $\mathrm{MgSO}_{4}$ ATPS was used to partition spleen proteinase from

2 three tuna species (Table 3). With ATPS partitioning, higher folds of purification

3 were obtained for splenic extract of yellowfin tuna, compared with those of tongol

4 tuna and skipjack tuna. The recovery yields were of 69.2, 73.6 and 82.5 for yellowfin

5 tuna, skipjack tuna and tongol tuna, respectively (Table 3). Different protein

6 compositions among three species possibly affected the partitioning of proteinase in

7 ATPS used. It is also speculated that differences in the level of purification fold after

8 ATPS process among tuna species might be related to different physicochemical and

9 enzyme properties. Most of the methods reported for proteinase purification from fish

10 digestive organs involved several steps, including ammonium sulfate precipitation,

11 size-exclusion and ion-exchange chromatography [14,15], hydrophobic interaction

12 chromatography [5] and affinity chromatography [29, 38]. In view of their

13 characteristics, these multi-step methods result in high cost and time consuming 14 purification process. Thus, ATPS could be an efficient method for the recovery of 15 proteinase from tuna spleen due to the ease and lower cost.

3.4 Protein pattern and activity staining of spleen proteinase from three tuna species partitioned with ATPS

The purity of the enzyme from three tuna species after ATPS process was analyzed by SDS-PAGE (Fig. 1). Crude splenic extract contained a variety of proteins

21 with different molecular weight. However, a large number of contaminating proteins 22 were removed after partitioning with ATPS, particularly proteins with higher or lower 23 MW. As a result, a higher purity of interested proteinase was obtained. When the 24 proteins or enzymes to be separated differ significantly in their structural properties 
1 from others, partitioning can be carried out successfully. The partitioning by ATPS

2 becomes more complicated when those differences are minor [21]. The proteinases in tuna splenic extract and fraction obtained from ATPS were

4 identified by SDS-substrate polyacrylamide gels (Fig. 2). The apparent MWs of the 5 major activity bands were estimated to be 48, 23 and $23 \mathrm{kDa}$ for skipjack, tongol and 6 yellowfin tuna, respectively. However, minor activity bands were observed with 7 apparent MW of 32 and $21 \mathrm{kDa}$ for tongol and 31 and $21 \mathrm{kDa}$ for yellowfin, 8 respectively. The results indicated the differences in the major proteinases in splenic 9 extract among all tuna species tested. Generally, activity bands of skipjack were 10 different from those of other two species. Slightly greater band intensity in ATPS

11 fraction was observed, suggesting the higher specific activity of proteinase loaded into 12 the gel.

\section{Conclusion}

Aqueous two-phase system was demonstrated to be an efficient primary purification step for the tuna spleen proteinase. The best condition of ATPS for

17 partitioning proteinase from tuna spleen was the PEG1000 (15\%)-MgSO 4 (20\%)

18 system. Scaling up two-phase partition could form part of future industrial purification protocols for recovery of tuna spleen proteinase. 


\section{Acknowledgments}

2 Financial support from Thailand Research Fund under the Royal Golden

3 Jubilee Ph.D. Program (Grant No. PHD/0216/2546) to Suppasith Klomklao.

4

5

6

7

8

9

10

11

12

13

14

15

16

17

18

19

20

21

22

23

24

25 


\section{References}

2 [1] Subasinghe S. Innovative and value-added tuna products and markets. INFOFISH Intern 1999;1:43-50.

4 [2] Klomklao S, Benjakul S, Visessanguan W. Comparative studies on proteolytic activity of spleen extract from three tuna species commonly used in Thailand. J. Food Biochem 2004;Accepted.

[3] Ooshiro Z. Studies on proteinase in the pyloric caeca of fish-II. Some properties of proteinase purified from the pyloric caeca of mackerel. Bull. Jap. Soc. Sci. Fish 1971;26:685-90.

[4] Kawai S, Ikeda S. Studies on digestive enzymes of fishes-II. Effect of dietary change on the activities of digestive enzymes in carp intestine. Bull. Jap. Soc. Sci. Fish 1972;39:265-70.

[5] Kristjansson M. Purification and characterization of trypsin from the pyloric caeca of rainbow trout (Oncorhynchus mykiss). J. Agric. Food. Chem 1991;39: 1738-42.

[6] Haard NF. A review of proteolytic enzymes from marine organisms and their application in the food industry. J.Aqua. Food Prod. Technol 1992;1(1):17-35.

[7] Joo HS, Park GC, Kim KM, Paik SR, Chang CS. Novel alkaline protease from the polychaeta, Periserrula leucophryna: purification and characterization. Process Biochem 2001;36:893-900.

[8] Manachini PL, Fortina MG. Production in sea-water of thermostable alkaline proteases by a halotolerant stain of Bacillus licheniformis. Biotechnol Lett 1998;20:565-68. 
1 [9] Kim HR, Meyers SP, Godber JS. Purification and characterization of anionic trypsin from the hepatopancreas of crayfish, Procambarus clarkii. Comp. Biochem. Physiol 1992;103B:391-98.

[10] Kim HR, Meyers SP, Godber JS. Enzymatic properties of anionic trypsins from the hepatopancreas of crayfish, Procambarus clarkia. Comp. Biochem. Physiol 1994;107B:197-203.

[11] Ramakrishna M, Hultin HO, Atallah MT. A comparison of dogfish and bovine chymotrypsins in relation to protein hydrolysis. J. Food Sci 1987;52:1198-202.

[12] Kim HR, Pyeun JH. The proteinase distributed in the intestinal organs of fish II. Characterization of the three alkaline proteinases from the pyloric caeca of mackerel, Scomber japonicus. Bull. Korean Fish. Soc 1986;19:547-57.

[13] Hjelmeland K, Raa J. Characteristics of two trypsin type isozymes isolated from the Arctic fish capelin (Mallotus villosus). Comp. Biochem. Physiol 1982; 71B:557-62.

[14] Bezerra RS, Santo JF, Paiva PMG, Correia MTS, Coelho LCBB, Vieira VLA, Carvalho LB. Partial purification and characterization of a thermostable trypsin from pyloric caeca of tambaqui (Colossoma macropomum). J. Food Biochem 2001;25:199-210.

[15] Byun HG, Park PJ, Sung NJ, Kim SK. Purification and characterization of a serine proteinase from the tuna pyloric caeca. J. Food Biochem 2003;26:47994.

[16] Silva MED, Franco TT. Purification of soybean peroxidase (Glycine max) by metal affinity partitioning in aqueous two-phase systems. J. Chromatogr. B 2000;743:287-94. 
1 [17] Park K, Wang S. $\alpha$-Amylase fermentation with Bacillus amyloliquefaciens in aqueous two-phase system. Biotechnol. Prog 1991;7:439-44.

[18] Seema GSK, Ahmed S, Singh SP, Mittal BK. Aqueous diphasis system for cell debris removal and partitioning of $\beta$-galactosidase from Lactobacillus acidophilus. Ind. J. Microbiol 1993;33:261-63.

[19] Sinha R, Singh SP, Ahmed SK, Grag SK. Partitioning of a Bacillus alkaline protease in aqueous two-phase systems. Biores. Technol 1996;55:163-66.

[20] Reh G, Nerli B, Pico G. Isolation of alpha-1-antitrypsin from human plasma by partitioning in aqueous biphasis systems of polyethyleneglycol-phosphate. J. Chromatogr. B 2002;780:389-96.

[21] Han JH, Lee CH. Effects of salts and poly(ethylene glycol)-palmitate on the partitioning of proteins and Bacillus subtilis neutral protease in aqueous twophase systems. Colloid Surf B 1997;9:109-16.

[22] Srinivas ND, Rashmi KR, Raghavarao KSMS. Extraction and purification of a plant peroxidase by aqueous two-phase extraction coupled with gel filtration. Process Biochem 1999;35:43-8.

[23] Gaikaiwari R, Shendye A, Kulkarni N, Mala. Two phase separation of xylanases from alcalophilic thermophilic Bacillus using a poly(ethylene glycol)- $\mathrm{KH}_{2} \mathrm{PO}_{4}$ system. Biotechnol Appl Biochem 1996;23:237-241.

[24] Andersson E, Johansson A, Hagerdal GB. Amylase production in aqueous twophase system with Bacillus subtilis. Enzyme Microb Technol 1985;7:333-8.

[25] Tanuja S, Srinivas ND, Raghavarao KSMS, Gowthaman MK. Aqueous two phase extraction for downstream processing of amyloglucosidase. Process Biochem 1997;32:635-41. 
1 [26] Li M, Zhu ZQ, amd Mei LH. Partitioning of amino acids by aqueous two phase systems combined with temperature induced phase formation. Biotechnol Prog 1997;13:105-8.

[27] Raghavarao KSMS, Rastogi NK, Gowthaman MK, Karanth NG. Aqueous two phase extraction for downstream processing of enzymes/proteins. Adv Appl Microbiol 1995;41:97-171.

[28] Diamond AD, Hsu JT. Aqueous two-phase systems for biomolecule separation. Adv Biochem Eng/Biotechnol 1992;47:89-135.

[29] Simpson BK, Haard HF. Trypsin from Greenland cod (Gadus ogac). Isolation and comparative properties. Comp. Biochem. Physiol 1984;79B:613-22.

[30] Garcia-Carreno FC, Dimes CE, Haard NF. Substrate gel electrophoresis for composition and molecular weight of proteinases or proteinaceous proteinase inhibitors. Anal. Biochem 1993;214:65-9.

[31] An H, Seymour TA, Wu JW, Morrissey MT. Assay systems and characterization of Pacific whiting (Merluccius productus) protease. J. Food Sci 1994;59:27789.

[32] Lowry OH, Rosebrough NJ, Fan AL, Randall RJ. Protein measurement with Folin phenol reagent. J. Biol. Chem 1951;193:256-75.

[33] Laemmli UK. Cleavage of structure proteins during the assembly of the head of bacteriophage $\mathrm{T}_{4}$. Nature 1970;277:680-85.

[34] Bradford MM. A rapid and sensitive method for quantitation of microgram quantities of protein utilizing the principle of protein-dye binding. Anal. Biochem 1976;72:248-54. 
1 [35] Isable DVM, Otero C. Biphasic aqueous media containing polyethylene glycol for the enzymatic synthesis of oligosaccharides from lactose. Enzyme Microbiol Technol 2003;33:118-26.

4 [36] Pan IH, Li YK. Rapid process for purification of an extracellular $\beta$-xylosidase by

5 aqueous two-phase extraction. J. Chromatogr. B 2001;754:179-84.

6 [37] Fernandez LHM, Miranda MV, Fralie ER, Bonino JMJB, Cascone O.

7 Partitioning behaviour and purification of a Mucor bacilliformis acid protease

8 in aqueous two-phase systems. Process Biochem 1995;30:615-21.

9 [38] Heu MS, Kim HR, Pyeun JH. Comparison of trypsin and chymotrypsin from the 10 viscera of anchovy (Engraulis japonica). Comp. Biochem. Physiol $11 \quad$ 1995;112B:557-67. 
1 Table 1 Effect of phase composition in PEG 1000-Salt ATPS on partitioning of spleen

2 proteinase from yellowfin tuna.

\begin{tabular}{|c|c|c|c|c|c|c|}
\hline $\begin{array}{c}\text { Phase conposition } \\
\text { (\%w/w) }\end{array}$ & $\mathrm{V}_{\mathrm{R}}$ & $\mathrm{K}_{\mathrm{P}}$ & $\mathrm{K}_{\mathrm{E}}$ & SA & $\mathrm{PF}$ & $\begin{array}{l}\text { Yield } \\
(\%)\end{array}$ \\
\hline 20\%PEG1000 - 15\%NaH $\mathrm{PO}_{4}$ & 3.23 & 1.55 & 8.15 & 12.71 & 1.76 & 69.7 \\
\hline $20 \%$ PEG1000 - 20\% $\mathrm{NaH}_{2} \mathrm{PO}_{4}$ & 1.31 & 1.29 & 33.59 & 13.37 & 1.85 & 57.4 \\
\hline 20\%PEG1000 - 25\%NaH ${ }_{2} \mathrm{PO}_{4}$ & 0.92 & 0.99 & 26.11 & 12.40 & 1.71 & 33.3 \\
\hline 20\%PEG1000 - 15\% $\mathrm{K}_{2} \mathrm{HPO}_{4}$ & 1.07 & 1.55 & 23.54 & 13.79 & 1.91 & 76.7 \\
\hline $20 \%$ PEG1000 - 20\% $\mathrm{K}_{2} \mathrm{HPO}_{4}$ & 0.91 & 1.25 & 35.89 & 14.46 & 2.00 & 64.1 \\
\hline 20\%PEG1000 - 25\% $\mathrm{K}_{2} \mathrm{HPO}_{4}$ & 0.74 & 0.78 & 22.89 & 12.42 & 1.72 & 40.0 \\
\hline 20\%PEG1000 - 15\% $\mathrm{MgSO}_{4}$ & 2.46 & 0.60 & 1.11 & 16.58 & 2.29 & 83.6 \\
\hline 20\%PEG1000 - 20\% $\mathrm{MgSO}_{4}$ & 1.33 & 0.32 & 1.77 & 24.55 & 3.40 & 71.7 \\
\hline 20\%PEG1000 - 25\% $\mathrm{MgSO}_{4}$ & 1.13 & 0.53 & 2.14 & 13.50 & 1.87 & 55.5 \\
\hline $20 \%$ PEG1000 - 15\% $\mathrm{Na}_{3} \mathrm{C}_{6} \mathrm{H}_{5} \mathrm{O}_{7}$ & 1.42 & 1.09 & 15.44 & 11.32 & 1.57 & 72.2 \\
\hline $20 \%$ PEG1000 - 20\% $\mathrm{Na}_{3} \mathrm{C}_{6} \mathrm{H}_{5} \mathrm{O}_{7}$ & 1.17 & 1.05 & 11.79 & 12.19 & 1.69 & 64.1 \\
\hline $20 \%$ PEG1000 - 25\% $\mathrm{Na}_{3} \mathrm{C}_{6} \mathrm{H}_{5} \mathrm{O}_{7}$ & 0.71 & 0.81 & 22.44 & 13.03 & 1.80 & 52.0 \\
\hline $20 \%$ PEG1000 - 15\%(NH $)_{2} \mathrm{SO}_{4}$ & 1.28 & 1.55 & 22.49 & 11.28 & 1.56 & 73.2 \\
\hline $20 \%$ PEG1000 - 20\%(NH$)_{2} \mathrm{SO}_{4}$ & 0.95 & 1.73 & 42.60 & 13.36 & 1.85 & 53.3 \\
\hline $20 \%$ PEG1000 - 25\%(NH$)_{2} \mathrm{SO}_{4}$ & 0.89 & 2.16 & 62.47 & 16.41 & 2.27 & 66.6 \\
\hline 20\%PEG1000 - 15\% $\mathrm{Na}_{2} \mathrm{SO}_{4}$ & 1.04 & 1.57 & 22.12 & 17.28 & 2.39 & 59.7 \\
\hline $20 \%$ PEG1000 - 20\% $\mathrm{Na}_{2} \mathrm{SO}_{4}$ & 0.84 & 2.10 & 24.49 & 12.14 & 1.68 & 44.7 \\
\hline $20 \%$ PEG1000 - 25\% $\mathrm{Na}_{2} \mathrm{SO}_{4}$ & 0.70 & 1.43 & 21.26 & 15.14 & 2.09 & 35.4 \\
\hline $\begin{array}{l}\mathrm{VB}_{\mathrm{R}} \text { : Volume ratio (Upper/Lower) } \\
\mathrm{KB}_{\mathrm{P}} \text { : Partition coefficient of protein } \\
\mathrm{K}_{\mathrm{E}}: \text { Partition of proteinases in the upp } \\
\mathrm{SP}: \text { Specific activity (U/mg Protein) } \\
\mathrm{PF} \text { : Purification factor } \\
\text { Yield : Recovery yield }\end{array}$ & phase & & & & & \\
\hline
\end{tabular}


1 Table 2. Effect of PEG molecular mass and concentration in a PEG-MgSO 4 ATPS on

2 partitioning of spleen proteinase from yellowfin tuna.

\begin{tabular}{|c|c|c|c|c|c|c|}
\hline $\begin{array}{c}\text { Phase conposition } \\
(\% \mathrm{w} / \mathrm{w})\end{array}$ & $\mathrm{V}_{\mathrm{R}}$ & $\mathrm{K}_{\mathrm{P}}$ & $\mathrm{K}_{\mathrm{E}}$ & SA & $\mathrm{PF}$ & $\begin{array}{c}\text { Yield } \\
(\%) \\
\end{array}$ \\
\hline 10\%PEG1000 - 20\% $\mathrm{MgSO}_{4}$ & - & - & - & - & - & - \\
\hline 15\%PEG1000 - 20\% $\mathrm{MgSO}_{4}$ & 1.03 & 0.14 & 1.94 & 46.87 & 6.61 & 69.0 \\
\hline 20\%PEG1000 - 20\% $\mathrm{MgSO}_{4}$ & 1.45 & 0.31 & 1.82 & 23.66 & 3.34 & 71.8 \\
\hline 25\%PEG1000 - 20\% $\mathrm{MgSO}_{4}$ & 1.87 & 0.51 & 2.13 & 16.04 & 2.26 & 68.3 \\
\hline $10 \%$ PEG4000 - 20\% $\mathrm{MgSO}_{4}$ & 0.73 & 0.35 & 0.56 & 11.14 & 1.57 & 37.8 \\
\hline $15 \% \mathrm{PEG} 4000$ - 20\% $\mathrm{MgSO}_{4}$ & 1.05 & 0.45 & 0.57 & 9.14 & 1.29 & 38.3 \\
\hline 20\%PEG4000 - 20\% $\mathrm{MgSO}_{4}$ & 1.54 & 0.60 & 0.74 & 7.00 & 0.99 & 36.2 \\
\hline 25\%PEG4000 - 20\% $\mathrm{MgSO}_{4}$ & 1.90 & 1.36 & 0.07 & 0.16 & 0.02 & 1.3 \\
\hline \multicolumn{7}{|c|}{-No phase separation } \\
\hline \multicolumn{7}{|c|}{ Abbreviation: See Table 1 footnote. } \\
\hline
\end{tabular}

7

8

9

10

11

12

13

14

15 
1 Table 3 Purification of spleen proteinase from three tuna species using 15\%PEG1000

$2-20 \% \mathrm{MgSO}_{4}$ ATPS

\begin{tabular}{|c|c|c|c|c|c|}
\hline Fraction & $\begin{array}{c}\text { Total activity } \\
\text { Units } \\
\end{array}$ & $\begin{array}{c}\text { Total protein } \\
\mu \mathrm{g} \\
\end{array}$ & 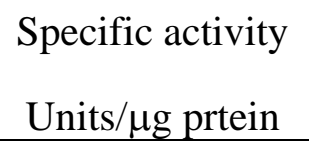 & $\begin{array}{l}\text { Purification } \\
\text { fold } \\
\end{array}$ & $\begin{array}{l}\text { Yield } \\
(\%) \\
\end{array}$ \\
\hline Yellowfin tuna & 10898.14 & 1551.77 & 7.02 & 1.00 & 100.0 \\
\hline ATPS ${ }^{*}$ & 7543.86 & 162.21 & 46.51 & 6.62 & 69.2 \\
\hline Skipjack tuna & 10588.54 & 1801.04 & 5.88 & 1.00 & 100.0 \\
\hline ATPS $^{*}$ & 7787.42 & 379.70 & 20.51 & 3.49 & 73.6 \\
\hline Tongol tuna & 10032.25 & 1889.59 & 5.31 & 1.00 & 100.0 \\
\hline ATPS ${ }^{*}$ & 8276.36 & 429.67 & 19.26 & 3.63 & 82.5 \\
\hline
\end{tabular}

4

5

6

7

8

9

10

11

12

13

14

15 
4

5

6

7

8

9

10

11 $\overline{\text { yellowfin }}$ skipjack $\overline{\text { tongol }}$

$\begin{array}{lllllll}1 & 2 & 3 & 4 & 5 & 6 & \text { L }\end{array}$

12

13

Fig. 1 


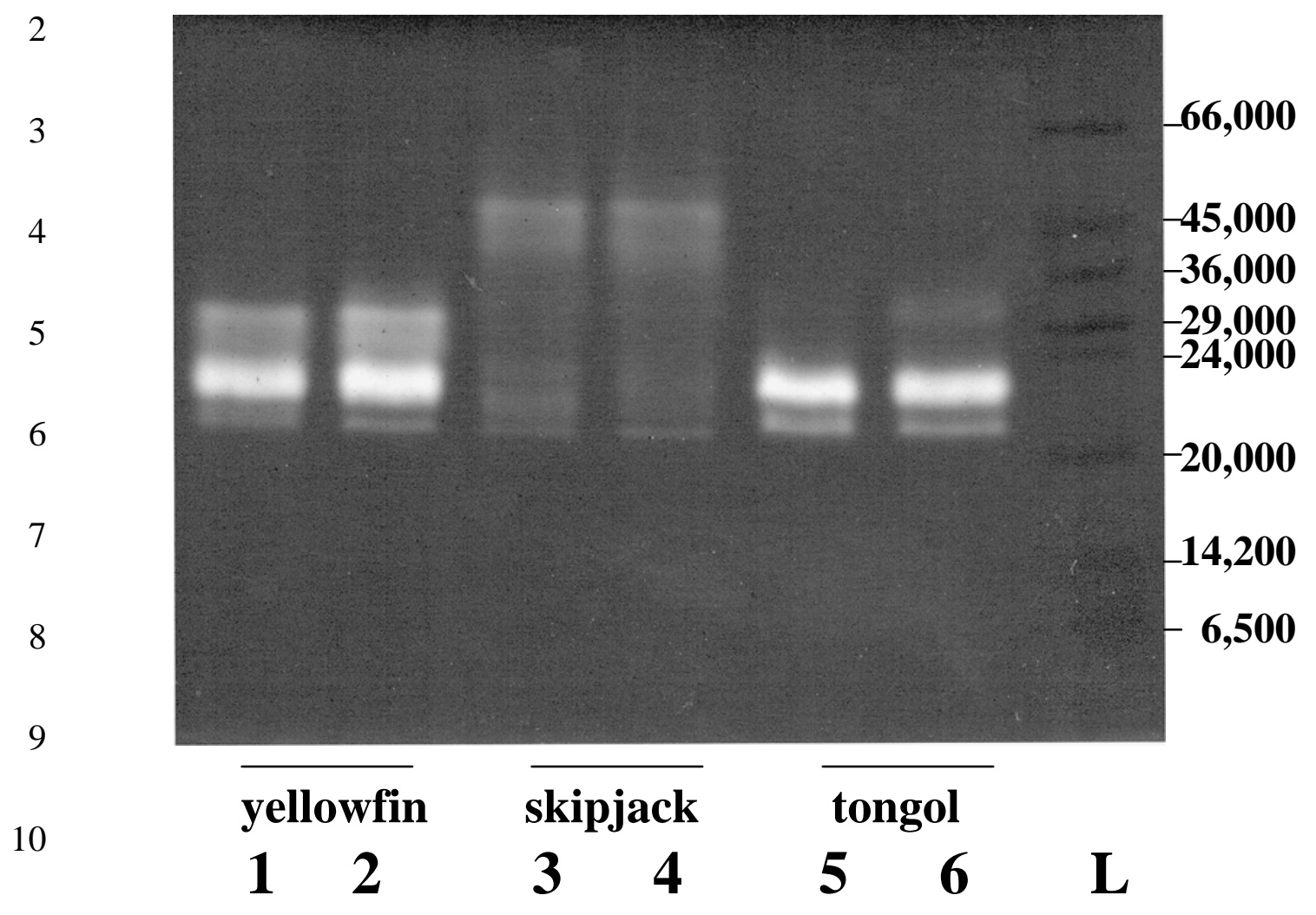

11

12

13

\section{Fig. 2}




\section{Figure Legends}

2 Figure 1. SDS-PAGE of spleen extracts and ATPS fraction from different tuna

species. L, Low-molecular-weight standard; lane 1,3,5, spleen extract; lane

4 2,4,6, 15\% PEG1000-20\% $\mathrm{MgSO}_{4}$ ATPS fraction.

5 Figure 2. Activity staining of spleen extracts and ATPS fraction from different tuna 2,4,6, 15\%PEG1000-20\%MgSO 4 ATPS fraction.

8

9

10

11

12

13

14

15

16 